\title{
可視化情報学会新春若手放談会*
}

\author{
岡本 孝司 ${ }^{* 1}$, 藤代 一成 ${ }^{* 2}$, 清野 聡子 ${ }^{* 1}$, 西尾 茂*3, \\ 水上 浩*4, 宗像 鉄雄 ${ }^{* 5}$, 李家 賢一 ${ }^{* 1}$, 川橋 正昭*6
}

\section{Talking on Visualization by Young VSJ Members}

\author{
Koji Окамото, Issei Fujishiro, Satoko Seino, Shigeru Nishio, Ko Minakami, \\ Tetsuo Munakata, Kenichi RinoIE and Masaaki Kawahashi
}

可視化情報学会法人化 10 周年という節目の時を迎え， これからの可視化情報学がどのような役割を果たしてい くかなど, 現在学会で活躍されている 30 歳代の学会若 手メンバーの方々に自由に語っていただいた。

川橋編集委員長およびコラムに記載の 7 名が, 平成 11 年 1 月 7 日, 神田神保町の学士会館に集まり, 約 3 時間に渡り放談を繰り広げた.

\section{「可視化情報学とは」}

岡本：今日はお忙しいところお集まりいただきましてあ りがとうございました． 新春若手放談会ということで, 自由に話していただければと思います。まず可視化情報 の定義について考えてみましょう．可視化というのは人 間が目で見るというところから始まっていると思うので すが, そこからどんどん広くなっていって, 多次元デー 夕を見ても可視化です．非常に広い，ある意味ですべて の工学の, 工学だけではなくてすべての学問を包括する ような概念になってきているかと思います。しかし，一 般の人は可視化というと, 何だそれはというところがか なりあると思います. そういうギャップも含めて, 可視 化の定義というのは何なのですかね.

藤代：最近ちょっといろいろなところで引用させても らっているのですけれど, 古本屋で湯川秀樹先生の『目 に見えないもの』という本を見つけました．目に見えな いものと書いてあるわけですから，これは読まないわけ にはいかない. 理論物理に入る誘いとしてはひじょうに 有名な科学随筆だそうで, その最後のエッセーのところ で, 書物は思想の凍結であり結晶であるという言葉が あったんです. $2 つ ，$ 光と影と両方あるということなん ですけれど，ご自分で本を書かれてしまうと，湯川流の 見せ方で若い人たちが原子物理の姿を捉えてしまう，そ の意味においては凍結だと.だけれど, 誰かわかる人が 書いてあげなければ本当の姿は見えてこないから，光の 面としては結晶だというのです. どちらの危険性もある

* 原稿受付 1999 年 1 月 21 日

*1 東京大学, ${ }^{* 2}$ 拈茶の水女子大学, ${ }^{* 3}$ 大阪府立大学,

*4 侏東芝, ${ }^{* 5}$ 工業技術院機械技術研究所, ${ }^{* 6}$ 埼玉大学
というので，半分ご自分のことを卑下していわれた最後 の言葉だったのです，マルチメディアの時代ですから， 本というのを可視化に置き換えてみると，可視化という のは思想の凍結であり結晶であると，僕は言えるような 気がします。うまくやれば結晶になるわけです。一番大 事なところだけのエッセンスをうまい形で，誰の目にも わかるような形にできる. それが可視化だと思います. でも下手すると, わざと歪めて可視化すると, その人の 恣意的なコンテクストで歪められてしまったものを見せ られた人は予備知識がないとそれが本当の姿だと思って しまうわけです，そうなってしまうと，実は凍結なんで すね. 実際にすでに例えばアメリカの CMU や Xerox PARC あたりでは可視化のことを Knowledge Crystallization と呼んでいるので, それを引用すれば, 可視化と いうのは知識とか思想の結晶化になって, 可視化情報と いうのは結晶化された思想ないしは知識かと思います.

西尾：我々は例えば何かの映像から情報を取り出したり， 情報を映像に直したりという作業を普段もしているわけ です．可視化というのは，もともとは見えないものを見 えるようにする, 流れの可視化は流れが見えないからそ れを何とかして見えるようにするということから始まっ たのだと思います．ここで，見えないものって何という 定義を一般化しますと, 多分見えるようにするというの もバラエティが広がって, もっと大きい定義になるので はないかと思うのです. 一方, 可視化情報という話にす ると, 可視化伝達という言葉があるかどうかわかりませ んが, 例えば藤代先生がやっているようにデータを人に 見せるようにすることが主になる．デー夕を映像として 見せるという方向と, 映像から情報を取り出すというよ

岡本孝司 (東京大学: 司会)
大学院時代の流体実験から可
視化に興味をもつ. 現在は,
可視化された情報から如何に
精度良く定量的なデー夕を取
り出すか, という多次元定量
可視化に興味をもち PIVな
どの研究を行っている.


藤代一成

(お茶の水女子大学)

数值解析, データベース, CG の研究を行う中で統合技術と しての大規模なデータの可視 化に興味をもつ. 現在は, 3 次元内につまったボリューム の可視化, 情報の可視化, 可 視化(マッピング)技法の体系 化に関する研究を行っている.

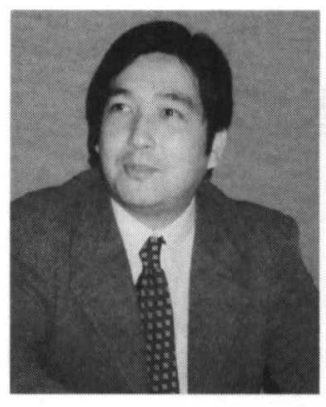

うな作業に何か分かれて進んでいるのかなという気が私 はしているのですけれど.

岡本：そうなると，先ほど藤代先生が言われたのは，情 報の結晶といいますか集約していく方向で，今西尾先生 が言われたのは結晶から必要な情報を抽出していくと. だから結晶も見方によってはいろいろな結晶があると言 うことだと思うのですが.

清野 : 両方の意見の中になるのかもしれないのですけれ ど. 可視化の研究をしていますということを言いますと, 可視化が写真みたいに一般化しているという先入観があ るような方には，写真は誰でも撮れるじゃないとか，そ ういうことを言われたりとかするんですよね．映像を撮 るまでにいろいろな技術が集約される，そのアウトプッ トが映像なんだというふうに言ったとしても，そのプロ セスが見えにくいからあまり理解されないんですね.や はり私はそうじゃないというところを，可視化というも のを, 今日の放談会で整理していくとか, 絵を撮るまで のプロセスというか知識がどうやって画像に落とし込ま れているかということを, 学問としてもアピールしてい くということが必要だなという気がしているんです.一 方で, じゃあ写真は誰でも撮れるじゃないというふうな ことを跳ね返していくということは重要なんですけれど. 確かに映像とかが汇濫して，見る人が見ればわかるし， そうじゃない人が見るとわからないということはあると 思うのです。 それをどのぐらいの知識がある人が見ると 何が明らかにできるのかということ，つまり，皆に見え なかったり解釈できなかったものがどう解釈されるかと いうことを，このような思考過程を含めて文章にしてい くということが学問としては多分必要になってくるんだ ろうなという気はしています.

水上: 可視化っていったら, 僕は集約するとプレゼン テーションだと思うのですよ. プレゼンテーションとい うのは見栄えがいいとかというのもあるんだけれど．例 えばいろいろな現象を追いかけているときに，きっとこ うなっているはずだというのがあるわけですよね. それ を流れの可視化なり何なりして確かめる. それを客観的 に人にわかってもらう。こんなこと知らなかったろうと いうものを人に見せたい. だから情報の可視化というも のも, それはもう頭の中ではきっと整理されている人が, 第三者にそれをわかってもらわなければならないので,
きっと可視化にしなければいけない.だから僕はやっぱ り自分の中に抱えている悩みなり何なりを人にわかって もらう．第三者にわかってもらうための手法が僕は可視 化だと思うし，僕自身も可視化のことは集約するとプレ ゼンテーションの 1 つのッール, 方法じゃないかなと. かなり乱暴ですけれど，僕はそういうふうに思っていま す. 自分の仮説を見えるようにするというのも含めて， そこの広い意味でのプレゼンテーションだというふうに, 僕は思っています.

宗像：僕は単なる見えないものが見えればいいと思って いますけれど, 何も難しく考えていないですけれど.

岡本 : 多分, この情報といったときに，その情報のレベ ルがすごくいろいろあって，ある情報を入れたら，別の 情報が出たときにどうなるというのも可視化だし，その 逆もまた可視化だと思うのです．だから可視化というよ りは, どちらかというと思想というか, 理解というか, 非常に広い哲学的な話になってきてしまいましたが.

\section{$\ulcorner 10$ 年後の可視化情報」}

岡本：さて, 今の可視化情報学というのはどういう位置 にあって, 今後 10 年後, 次の 20 周年を迎えたときに, 可視化情報学がどうなっているかと言うことについては 清野：多分ビジュアルコミュニケーションみたいなのが 一般化するのだと思うのです. それで例えば学会誌など も別に可視化情報学会に限らず，もうちょっと動画を取 り入れていこうということがほかの学会にも浸透したと きに, 10 年後の可視化情報学会はあまりに当たり前す ぎて，もういらないと言われるか，あるいは逆に全部を 包括するかというところですね. これを機に整備してお くということが重要なのかなという気がするのです.

宗像：ただ問題は, 昔は写真 1 枚可視化したというので, それで説明できましたけれど, 今はアニメーションつく ると. 確かにコンピュータとかパソコンが発達して, こ れから先, どれだけ発達するかわからないのですけれど, やはりアニメーションをつくるとかって, 結構労力を食 うんですね. だからそれがどこまでこの 10 年でいくの かなというのは，すごく興味を持ってはみています.

藤代：もうコンピュータリテラシーの 1 つになっていく んじゃないですか, 可視化. 特に理系, まあ文系の方も そうでしょうけれど，水上さんがおっしゃったようにプ レゼンテーションして, あるいは発見的に使っていくと きの道具として，どの人も等しく勉強しなければならな いようなものになっていくという気がしますけれどね.

岡本：恐らくそうですね, 今の CG とかプレゼンテー ションとか，そちらの方の分野は 10 年といわず，多分 2,3 年でそうなる感じがあるとは思うのです.

藤代：今日は放談会なので, 大風呂敷を広げてしまい, 話を発散させてばかりで申し訳ないのですが，今日もう 1つ言いたかったことがあります. 実はF.P.Brooks, Jr. の不等式 (IA > AI) といわれているものがあります. IA 
は Intelligence Amplification でAIはもちろん Artificial Intelligence です，考えてみると，計算機屋の立場とし ては, 何でこの 10 年ぐらいの間にこれだけ 3 次元の可 視化が流行ったのかと思ったら，結局それは 3 次元のグ ラフィックスが結構使えるようになったからというのが, 大きな理由の 1 つだと思うのです．結局それが知識増幅 に使われていたにすぎないですね．頭の中で単にイメー ジしていたのを，具体的に絵にできるようになった，で すからそれぞれのディスプリンで活躍されている方が器 用にそういうものを使われて絵をつくり始めたのです. でもその F.T.Brooks のすごいところは, IA は適当な AI よりははるかに尊いと彼は言ったのです，ただですね，

僕が思っているのはここ 10 年ぐらいで，もう 1 回この 不等式の向きが逆になるかもしれない.つまり今は全部 人間は可視化されたものを見て，画像を見て判断してい るのですけれど, その判断の中のすごく基本的な部分, そういうある程度可視化計量に関係するところのいくつ かのエッセンスは, 計算機側がやってしまう。 それ以外 のもっと高度な組み合わせていく知識発見の部分はもち ろん人間がやる. そうすると何となくわからないですけ れど, 10 年とか 15 年周期で, 僕は IA と AIがひっくり かえっている気がしているのです，そうすると今ちょう ど下火ですよね, AIが. 僕はこの 10 年ぐらいでまた上 に上がってくる，次にそうなってくると，AIの主要な 応用テーマの 1 つが, 僕は可視化になるような気がして ならないのですよ.ですから, 多分学問研究の最先端の ところは，そっちにまた埽還するかなと．多分また失敗 するんですね，それでまたその時点では AIにまた戻っ て，また戻って，それがただスパイラルでどんどんどん どん半径を広げながら大きくなっていって，いっかは人 間の知能に近づけばいいなという図式が，僕の頭の中に はあります.

ですからこの 10 年はそういう要素技術，もう計算が すごくできるようになりましたよね，そうなると，可視 化情報学会としては，そういう方向性をリードしていか なければいけないかなと、トレンドをやはり追いかけて いって紹介して，もしそういう方向性に皆さんがいくの であ机ば，いち早くそういうのを察知してですねという ふうに思うのです。

西尾：いや，ただし，多分大局的な見方だと思うのです が, ここ 10 年の可視化学会, 今のトレンドというのは, 多分皆さんおっしゃっている, 実験からコンピュー夕に 移管の 10 年だったかと思うのですね.ずっと皆さん手 元にコンピュータがある時代になって, コンピュータを 使うとこれができる，こんなこともできる，こんなにき れいになりますよということで，それは多分次の 10 年 ももっと進むだろうというのが，言ってみれば延長線だ と思うのです．ただこれは私の希望も含めてなんですが, 本当にそれでいいのかなと.これ可視化学会の危機じゃ ないかと私は逆に思うのですけれど.1つはそのトレン

\section{清野聡子 (東京大学) \\ 高校生時代に流れの可視化と いう分野を知り，映像に興味 をもつ. 生きている生物を映 像で捉える映像生物学の分野 を切り開く．現在は他分野融 合による新しい映像生物学研 究の推進と, 教育への応用な どに関して研究を進めている。

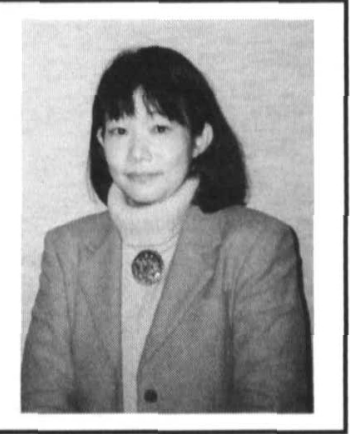

ドはもちろん主流になってどんどん進めていったら，可 視化学会のレベルは上がると思うのです. しかしもう 1 つは実験からスタートしていった私などにとっては, 原 点の見えるようにするという事の持っている説得力とい うのがすごいものがあったりする. それが動いたりなん かすると，何も言えなく，することもできない．ただそ れをやろうと思うと，私はわかるけれどあなたはわから ないという画像じゃだめだと. それは長い経験とか知識 の蓄積とかというのがあって, それは何かもう一遍見直 して, 10 年ぐらいでコンピュータだけじゃないよと. コンピュータだけの可視化学会の講演会だったら, 論文 だけで良い気もする．ここに来ないと見えないよという のも，もう1つトレンドがあってもいいんじゃないか. 3つストーリーを僕は持っていたのですけれど，もう 1 つのストーリーは可視化というのはどうしても実験室と か小さいレベルのところでの可視化であって, 最近清野 先生がやられているのは生物とか, あるいは写真などの 海洋のワンダービューとか衛星写真とかという, あるい はもっと会社の人にとっては例えば製造ラインとか，そ ういうところでのもっと, 実験室でちまちまやっていた のではなくて, もっと実用化とかもっと大きいところに いくようなストーリーもあってもいいんじゃないか，い やあってほしいなという気持ちでいるんです.

岡本：そうですね, 今抒二人の方に今後の方向性という のを言っていただいたのですが, 恐らくここ 10 年進ん できて，また元に戻る，もしくは摇り返すというのは, 今までの人間の技術の発展というのがそれぞれやってき たから，ベクトルの方向は違うにしろ，多分同じような 感想を持たれている方もいると思います.

李家：流体の問題にまた戻ってしまいますけれど, 先ほ どの西尾先生の括話に関係して, 多分西尾先生のご研究 なさった三次元流れの剥離でもそうですが, 10 年後に は三次元空間の任意の点の流体情報ということが全部わ かるようになる可能性があります. そうすると大量の データが実験で得られる. そしてその可視化もできまし たよと, そこまではいくと思うのです. しかし, 問題は そこからで, 大量のデータが出てしまって, それをどう 解釈していいのかということが, 多分わからなくなる恐 れがあるんです.昔でしたら, 二次元の写真 1 枚だけだっ たので, そこからいろいろ類推して論文を書けました. しかし大量のデー夕が出る時代になってしまうと, 三次 
元のデータを計測したけれど，結局また元に戻って，も う 1 回二次元の写真を撮って考え直す.そうやらないと 人間の頭が追いつかないかもしれないなということです. 岡本 : そこのところで, 恐らく藤代先生などがやられて いるような大量のデータからいかに意味のあるデータを 抽出するかという研究が重要になってくるのかなという 気はするんです. 恐らく, 元の話に戻りますけれど, レ ベルがいろいろあって, 人間のわかる範囲っていうのは, おっしゃるとおり，多分二次元までなんですよね.

清野：その辺は開発できないんですかね.

西尾：何とかならないですかね, 三次元を認識する教育.

清野：そうなんですね. そうじゃないと, やはり可視化 の研究って, 方法論を研究しているんでしょうとかいう ふうに言われます. 方法論ということ自体のインテリ ジェンスはあまり認めてもらえなかったというのが, か つてあったのですね. だからその中で例えば三次元とか 四次元というものを, 今は多分直感とか, 弟子と師匠み たいな中でやられていくようなものが, 教育の中ででき ればとも思います.もうちょっと一般化するとか, 何か その辺の人間の認知能力の拡張みたいなものがあっても 良いと思います. 例えばファーブル昆虫記というのから, 今の昆虫学にどういうふうにシフトしたんだというとき に, ファーブルさんは昆虫をよく知っていて, それを表 現する言語能力があるから観察学みたいなのはあれはあ れで 1 つ完結しているんですよね. その次に写真とかが 出てきて, 証拠を取り始めたんだけれど, スチールだっ たから行動とかが示せなくて, 今度ビデオが出てきたと きに，そうするとビデオを見ると，昆虫をやっている人 は大体, ああこういうことねってわかってしまうのでテ キストに落とさないのでもいいんではないかと言い出す 人も出てきます. 何かそういったときに, 人間の認知能 力が映像とか三次元とかが入ってきたときに, どんどん 発達があるいは拡散してきたというのはあると思うので す. 先ほどの $\mathrm{AI}$ か IA かという中で, 人間の認知能力っ て知らないうちに拡張されてきていて, そこを整備して いくような仕組みまで提案できるのかと.

水上：僕は可視化という言葉が実は気にくわないんです よ. 何で見るだけなのという, 触ってもいいじゃないの というのがあると思うんです. だから人間の五感の中で 確かに視覚によっている部分でやはり半分以上を占めて いると言われているわけですから，見るというのは一番 大事なことなんだけれども, 例えば三次元の流れを理解 するときに，例えば流線を針金でつくりましょう。それ

西尾茂 (大阪府立大学) 大学時代に回流水槽内の可視 化写真を取ろうとしたが, 結 局撮影に失敗した事により可 視化研究に興味を持つ. 現在 は, 海洋流や風波など海洋関 係の可視化計測を行っている.
が複雑に絡み合っているでしょうというのがいじくれた ら, 三次元の流れはもっと理解しやすくなると思うんですよ.

でもいずれにしても目で見ている，画面の上で三次元 であろうが何であろうが, 結局二次元の表面で見て, 回 して見てもいいんだけれど, そういう場面で認識すると なると, やっぱり人間の認知能力って結局二次元が限界 なのかなという話になると思うんだけれど, 手で持って, いじくれて，もしかして中に入り込んでいけてね.

宗像：それは人工現実感じゃないですか.

水上：まあバーチャルリアリティだと思うんですけれど. そういう部分が僕はもっと必要だと思うし，だから可視 化という言葉はあまり気にくわないですね. 可視化情報 学会というのは, 僕は名前がよくないんじゃないかと思って いるんです, 実は. 可触化, いや臭いもあるんですね.

藤代：学会ではもう常識になったのかもしれませんけれ ど, 僕のやっているフィールドだと, 名付け親はアメリ カの海軍研究所の Larry Rosenblum という人ですけれ ど, ビジュアリゼーションと言わないでリアライゼー ションと呼びましょうという言い方をしていますね.あ る仮想空間に没入させて, 没入すると人間って観察し始 めるらしいので, そういうふうに没入させる技術って結 構重要で, そういう見方をしている人もいらっしゃいま すよね. ですから，見るというか，要するにイメージさ せるという言い方があると思うんですけれど，イメージ させるというのは, 別に絵を思い浮かばせるのではなく てわからせるという意味ですから, そういうものとして 可視化というのを呼んだらいいと思うのですけれどね.

狭い意味に考えてしまうと，確かにすごく狭いです．表 すことはあまり多くはないという気もします.リアライ ズというのは完全に理解するという意味だそうです．塞 現するとか, そういう意味, 具現化するとかという意味 だけではないみたいですけれども.

岡本：やっぱりそうすると, 人間との関わりというのが 一番重要になってくると, 皆さんは.

藤代：すごくあるんですよね.

岡本：映像にするのが目的じゃなくて.

西尾：映像を理解するのが目的.

藤代：いろいろな名前があったのですけれど, ビジョ ン・サイエンスなんていう言い方もしていますよね. 理 解するまでのプロセス, そことビジュアリゼーションと いうのは切っても切れないというか.

水上：そういう意味では 10 年前から 10 年たって, 流れ の可視化学会が, 可視化情報学会に変わって, 情報とい うのが入ってきて, この 10 年先を考えると, あるべき 論ですけれど, また 10 年後ぐらいにこういう懇談会に 出たときに，面子がこういう面子ではだめだと思うけれ どね. もっと全然違ったフィールドの人が, 下手したら， それこそ文化系と呼ばれるような人たちが入ってくるよ うな世界でなければいけない.だからもっといろいろな 分野の人, いろいろな価值観を持った人というのが, 10 
年後には集い会えて，僕なんかもう関係ないんだけれど， じゃないといけないなというあるべき論だと思うんです けれど.

$$
\text { 「シミュレーションと可視化」 }
$$

藤代：1つ専門の先生方にお聞きしたいなと思っていた のですけれど, 僕なんかの分野だとジャクスタポジショ ンという言い方をする概念がありまして, 日本語に直す と並置化というのですか, 並べて置く．もともとアメリ カの物理学会の人たちが言っていた言葉ですけれど, 要 するに理論モデルの数值シミュレーションから出てきた 結果と, 実験データの突き合わせなんですよ. それって 流体の方でどのぐらい進んでいるんですか.

清野: 気象学だとか天文学とかだと, 理論的に予想され ていて，見えるようになったら本当にあったとかですね， そういうのはありますね.

岡本：恐らく我々はそれをやっているんだと思っている んですけれど. 流体屋さんというか機械屋さんというの は，基本的にはシミュレーションをやっておられますし， 流れの可視化もやっていて, 逆にいうとシミュレーショ ンの方でこういうところがあるはずだといって，そこを 探して, 流れを可視化してみたら同じようになったと， そういう経験は僕もありますけれど. だからそこはモデ ルがどこまで正確かとか, そういうことによってくると 思います，そうしたときに，逆に先ほども李家先生の話 にも出ましたけれど, モデルに結局フィードバックせざ るを得ない, アウトプットからフィードバックかける, 大量のデータが出てくれば出てくるだけ, 我々としては フィードバックかけやすくなるだろうと信じてやってい るんですけれども, そこは今度誤差との戦いとかなって くるのかなと, 僕は思ってはいるんですね.

藤代：フィードバックをされるのだとすれば, それはす ごく学問的ですよね. だと思うんです. 狭い意味でのプ レゼンテーションで見せっぱなしではなくて, 理論的な 検証をしつつ, そういうものをどんどんインプルーヴし ていくという, 繰り返しの仕組みができれば素晴らしい ことだし, その辺を先ほどから整理されるというお話を されていましたけれど, うまく整理をされて方法論的に 確立するものにしていくとか, そういうようなことがあ るでしょうかね. 外野からいうと, そういうのはすごく 気になるんですけれど.

西尾：生産現場ではやっているんじゃないかな.

水上：やはりシミュレーションと実際の実験と合わせる というのは皆やっている, ある程度やっていて, やっぱ り言いよどんでいるのは何をもって合うかというのは難 しい質問です。ミクロに見たときに，自分が一番見たい ところ, 剥離とか見たいところ, あってないじゃないの と,こう言う人もいるわけでね.

藤代：そのあたりを, 何か先ほどの AI と IA の話じゃ ないですけれど，そういう専門家の方の見方みたいなの

\section{水上浩（東芝）}

博士課程の頃, 熱交換機フイン 周りの流れを 7 色染料を用いて ミキシング状態を可視化した頃 より可視化に出会う. その後, 可 視化を含む熱流動研究に従事. 現在は環境保全の仕事を行っ ており直接流れの可視化とは関 係無いが流れ以外の可視化に 興味をもっている.

がルール化されるなり，アルゴリズム化されるなりして， それを少し高等なビジュアライザーがある程度やるとか, 見たいところを探させるなどというのもすごく重要な仕 事ですよね. そういうのってやれたらいいなと思うので すけれど.

水上：それは本当に主観の世界なので, これはなかなか 難しい. 方法としては, やっぱり計算と突き合わせて合 う合わないというのは, 本当に昔からやっていて, やっ ぱりある程度モデルにフィードバックするという話もあ りましたけれど, 要点さえきちんとしていればそれなり には絶対合うわけですね. 計算というのは, それだけの 地位は築けていると思うし. 今企業に僕いるわけなんだ けれど，企業でどういうことをやっているかというと， 何か物を開発します．そういうときに，いちいち昔は試 作品をつくって計測をして, 全部トライアンドエラーで やってきました. 今はコンピュータシミュレーションが それに取って代わって, 試作の回数が大幅に減っていま す. シミュレーションで, そういう開発期間を大幅に短 縮する, 試作の数を減らす, 実験をずっと減らす. 最後 に 1 回だけ確かめて, 世の中に出すというアプローチに なってきているから, ある程度はもう合うというのは, 完全に確立された地位があるんですよね. ただ学術的に それを見たときに，合う合わないというのはまだまだ難 しい. 企業サイドではそんなところなんで, もう随分合 うという方向で考えられて使われています，それは間違 いない. そのときには, ビジュアリゼーションはいらな いわけですけれど, 学問的な興味の方はまだまだ尽きな いと思います。その辺は難しいんでしょうね.

西尾：工学的な立場から言うと合わなくてもいいんです よね. 合わなくても, 設計者がそのいくつも合わない例 を見ていて, 合わないなりにそれをいくつも並べて,ぱっ と製品で合わせればいい.

水上：そうですね，そのと㧍りですね. シミュレーショ ンの弱点を知っていればいい.

\section{「ビジュアルアブストラクト」}

岡本：話が変わりまして, 情報発信について考えてみま しょう. 基本的にはビジュアリゼーションツールという か, プレゼンテーションツールはどんどん可視化の手法 が取り入れられているというこのときに, じゃあ可視化 
学会としてはどういうことを考えて，どういうことを やっていったらいいか. アメリカなんかはほとんどオン ラインジャーナルですよね. 紙のジャーナルはどんどん 隇っていっているというところが多くなってきていて. しかし，オンラインジャーナルの欠点というのは読まな いんですよね，なかなかやっぱり．アブストラクトだけ 見て，面白そうなのだけクリック，いちいちクリックし なければいけない。紙だと.

宗像：ぱらぱらぱらとめくれる。

岡本：ぱらぱらっと見て，それこそ可視化なんですけれ ど, 絵を見て面白そうだなと思います，そういう意味か らすると従来の紙が絵で見て判断していたのが, 今度は 一次元の文字列として見ていかなければいけない，とい うことであれば，それこそ論文のプレゼンテーションと いう意味でアブストラクトとタイトルだけで本当にいい のかということもありますけれど.

水上：でも我々は本で馿染んでいるから，ぱらぱらっと 見られるといいなとつくづく思うんですけれど. 今の若 い人って, 今コンピュータの方が親しんで育ってくるよ うな世代というのは, 本っていうのは扱いにくいなと思 うものになるんじゃないかなと.

岡本 : 情報検索という意味からすると, コンピュー夕の 方は結局キーワード検索なんですよね.

水上：いやいやそうじゃなくて.

宗像：それは時代が決める.

水上：いやもしかしたらデイスプレイの上でぱらぱらっ と流れるかもしれませんよ.

西尾 : コンピュー夕と文字をひっつけなくてもいいんで すよね. 凸版印刷から始まったわけで.

水上：文字からしてもう古いと.

西尾: 可視化学会こそ, 今のメデイア化に一番乗れるん じゃないかと思うんですけれど. 今までどこも报えな かったし，扱ってくれなかったし．可視化学会なんだか ら，1枚絵と題名を渡せばコンストラクトやると.

水上：いいですよね.

西尾：絵で検索して。 これ面白そうな絵だといって中身を。

水上：もともと画像を扱っている学会なんだから, そう いうマルチメディアというか, メディアを駆使するミッ ションというのは背負っているのでしょうね. それをや れるのは多分可視化学会が一番近いのかなという気がし ますよね.

岡本：動きやすいぐらいの規模だとは思いますね.

水上：いいね, アブストラクトを書かないで, 絵だけぼ んと乗せるんです．これが俺の結果だといって。

西尾: 目で判断すると.

水上: そういう学会があってもいいですよね.

清野 : 結構若い人でマスターぐらいからビジュアリゼー ションの仕事させられている人なんかは, すごい悩んで いる人が多いですよね, 先ほどの方法論じゃないのとか, その絵がこれで決めだから, それ以上だらだら書いても,

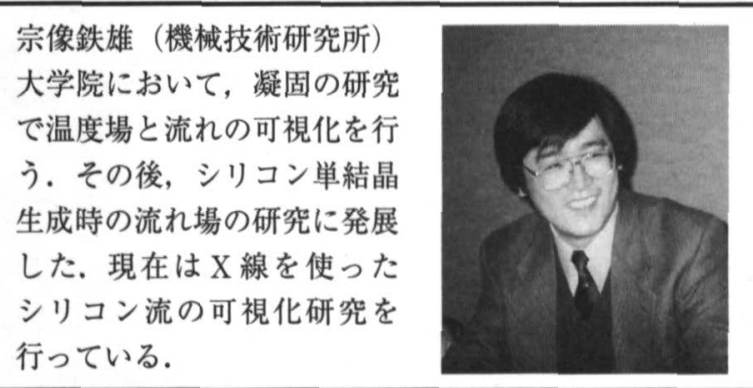

あまり文章の方を読んだ人がいなかったりとか，そうい う点である特化した部分というのを考えておくというこ とは, すごく重要ではないでしょうか.

宗像：そういう意味ではこれからジャーナルはPDF 化 というかCD 化をしていくという形なんでしょうかね.

岡本：そうだと思いますね, 恐らくそういうッールを 使って.

宗像：それで印刷はもうしなくなってくるんですかね.

岡本：印刷はしなくなってくる.

宗像 : で, オンラインで学会の事務局か何かにアクセス すればすぐそれが持ってこれるようになる。

岡本：持ってこれます．ただパスワードぐらいでプロテ クトかけるという格好になると思います。もう実際に APS とか OSA 等はそういう格好でジャーナルを出して います．ところで，動画というのは結局我々受動的に見 ているだけですよね.もう一つ進んで，それこそ藤代先 生がやられているような CG だと, 逆に見る位置をイン タラクティブに変えていく，そうするとVRMLですか, そこら辺を使ったようなジャーナルというのも.

藤代：すごく大事でしょうね. 可視化の良さの 1 つはや はり一人称的な視点を提供できるということだと思うん ですね. 誰かが見た目じゃなくて, 自分の目で、論文の 評価も読者がそういう目で見直せるというのはすごく重 要だし,もう1つは引用率って結構論文の評価になる じゃないですか. だとすれば, ウェッブでアクセスの率 とか, そのレスポンスとか, そういうので評価を決めて 学会賞とか出されるとかですね.

宗像：でもそれは難しいですよね，ある意味では，その データにアクセスしたからといって, それが必要だった からかどうかというのはわからないので.

藤代：ですから，もちろんそれはアクセスしただけじゃ なくて, ある種の反応を示してもらって. 特定のレフ リーを置かない, 置いた上の方がいいのかもしれません が, 読者をレフリー化するということです.

西尾: 候補選びにはいいかもしれませんね. 最終決定を それでやるのは問題があるかもしれませんが.

藤代 : 恐らく，そういうことを今後実験的にでも何でも， 多分ここ 2,3 年のうちにやる必要はあるのかなという気 がしますね.

李家：この間ある先生がおっしゃっていたのですが, オ ンラインジャーナル化に関して, 若い人はいいんだけれ ども，定年で仕事を辞めるとネットワークにアクセスで 
きなくなる. 学会の情報がウェブからしか入らなくなる と, 自分たちは取り残されるんじゃないかと. 今の印刷 物でしたら送られてきますから，会社を辞めても見る人 はずっと見る.

宗像：ジャーナルの印刷物プラスそういう映像だけの CD が付属するという感じなんですかね.

李家：しばらくの間は二者並立して, 両者を使ってやっ ていく.

岡本: 多分 10 年後にはそれこそ各家庭に端末があって, リタイアされた先生でもアクセスはすぐできる，電話と 同じ状況になると思うんですよ.

西尾：僕はそっちの方に期待しますね.メディアにはあ まり信用していなくて.

李家 : 情報が消えることに関して, 紙の場合は少なくと も数千年もったことは歴史的に証明されていると思いま すが, 電子メディアが今後我々の死んだあとも残ってい るかどうか.

清野 : 図書館なんかやはりそれを心配しますよね. 学術 誌, どういうサポートになるんですか, オンライン化, ジャーナル化していったところとかは.

岡本：一応 ISSN というのは全部ついているわけですよ ね. 図書館なんかはどんどんどんどんデジタル化を推進 していますよね，今。

宗像：場所がないですからね.

水上：管理楽ですものね. でも何千年といわれるとね.

$$
\text { 「ビジュアルデータマイニング」 }
$$

清野 : 先ほど結晶の話が出ていましたけれど, 例えば地 球科学だとか生物学, 地球科学って, 私が見ていて思う んですが, すごく画像のデータとか映像のデー夕って過 去からも含めて地図とか結晶構造とかの写真, すごく 持っているんですけれど, それはもう今までの形式だと 論文の 1 論文あたり 3 枚とかで, あとは全部捨てていて, 眠っているデー夕というのはすごく多いんですよね. そ こをもうちょっと映像資産というのが各分野に全然使わ れないまま眠っていて，それを活用する技術とか考え方 とかを毫引していくと, すごく進むんじゃないかなとい うことを最近思っているんです. 特に, 私最近海岸の地 形とか, 要するに海洋環境というのは生物はいなくなっ

\section{本家賢一}

(東京大学：編集委員会幹事) 航空機設計に関連して翼周り の流れの可視化実験を行う. 昔の学会誌表紙に載っていた 翼の可視化写真に使われてい た煙風洞も使っている. 現在 の専門は航空機設計であるが, 編集委員として流れ以外の広 範囲での可視化にも興味を もっている.
てしまうし，どんどん人間が変えてしまうのでわからな いので, 日本の戦後から撮り始める空中写真というのを 使って, どこまで生態系を復元できるかという仕事を やっているんです，そうすると映像資産というのはすご く日本国は持っているんですけれど, 誰も使わないし, そういう用途には使っていなかったので, 過去の映像資 料とかを,もうちょっと体系化して復元していくとか, ああいうのを活用していくということがわかったら，捨 て去られている分野の映像, 例えば文化系の民俗学など もそうみたいですけれど, そこを何かインテリジェンス に組み入れていくという方法を提示していったらと.

藤代：関連分野で情報処理の方では, 今注目を浴びてい るキーワードの 1 つにデータマイニングというのがある んです. データマイニング, つまりデータの山から鉱脈 を発見する. その前にビジュアルデータマイニングとビ ジュアルをつけて, アメリカなどではほとんどイコール， インフォメーションビジュアリゼーションです. VDM という言い方をしています.ですからマイニング学会なんて.

清野：本当それはすごい面白いと思いますね.

藤代 : データベース屋さんて結構うまいキーワード探す んですよ. 大体溜めることもできたし, 目下検索に戻っ ているんですね. そうするとただ検索してもしょうがな いから, じゃあ絵で検索しましょうと, そうするとさあ 何て名前をつけようと, それでデータマイニングと呼ば れる、あとありますよ, いろいろ, インフォメーション ドリルダウンとか. うまいですよね, 掘り下げているわ けですよね. 説明するときに, やっぱりキーワードが必 要ですから, そうするといろいろな人がいろいろな言葉 を言っているでしょう.でもよく聞いてみると同じこと を言っていて.

岡本 : そういうのは可視化情報学会の 1 つのアクティビ ティとして考えていっても面白いでしょうね.

藤代：株価の動きを見るなんて, そういうところで皆今 データマイニングなんて, 過去の動きからどうするかと か, 本当にできるかどうかわかりませんけれどね.

西尾：金鉱ですね.

水上: 本当のね.

\section{「学際領域としての可視化情報学」}

岡本：ちょっと飛びまして学際領域, あるいは他分野に 関わる共通基盤としての可視化情報学という事を考えた いと思います. 逆にいうと可視化情報学というのはすべ てを包含しているという認識であると.

西尾：僕は可視化という名前，悪くないと思うのですよ. それは意味するところが何だというのは多々あると思う のですがユニークです.こんなユニークな日本語という か, ビジュアリゼーションもユニークな英語だと思うの ですけれど, これを持っている学会というのは少ないの じゃないかなと. それは例えば学会に何を期待するかと いう話にもなると思うのですが，先ほどおっしゃったみ 
たいに，何か可視化学会に失礼な話ですけれど，皆さん 主流のところをどこか持っておられて, 可視化学会に来 ておられる. 可視化一本でいっていますという人は, 私 疑うのですけれどね.これは学会にとっては失礼なんで すけれど,でもそれが僕は違う会員に期待しているとこ ろで, こうやってくると, いろいろな話が聞けて, ほか の分野で当たり前のところを, 私の分野に持って皮ると 非常に貴重だったりする. そういうところで生きていっ ても, 1つぐらいそういう学会があってもいいんじゃな いかと私は思うんです.

水上: 確かに可視化情報学会というのは, いろいろな人 と会えるというのが非常に大きくて, 可視化情報学会が なかったら藤代先生とか清野先生と, 私が会うことはで きなかった. まして葛西の水族館に私が魚を見に行くと は思わなかった.

岡本：となるとそういう位置づけとしての, 学際, フュージョンといったところに可視化学会の 1 つのメ リットがあるということでしょうか. 敢えて 1 つのと申 しますが, それは今後恐らくずっと続いていく.

西尾: それを低いレベルで, いやちょっと私のところで いらなくなったから貸しましょうかというレベルじゃな くて, 可視化学会をオールスターにすればいいと思うん です. 各分野のトップの人たちが出てきて, そこにいけ ば皆トップのことがわかると. 共通基盤は何かというと 可視化というのがキーワードになっているということに なれば,これはいいなと. 学生会員も増えるんじゃない かと思います。

清野: 私, 実は自分の学科も学際学科というふうに言っ ていて, このあたりいつも問題になります. 学際学科と か学際学会というのは, それぞれ足場が合った人が出会 う場所だという定義がなされてしまうと, 今度はじゃあ 学際学のプロパーというか, この場合だと可視化情報学 のプロパーというものはいつになっても育たないんじゃ ないかということを思うんです，だから自分自身もそう だし, 若い人を育てるときも, 可視化情報学というもの を本気で育てていかないと, 多分いつになってもサロン 的だというふうに言われる恐れというのはあります.

だから可視化そのものに専念していく人も, コアにな る人も絶対必要だということは思います. 私は最近は可 視化にシフトして, 目で見るというか, 可視化というこ とで自然環境の中で何が解決していけるかというところ を見ていこうかなというふうに思っているんです．そう いった部分でやっていければと思っていますし, 可視化 情報学のプロパーというのはやはり強固にしたいという 強い意思が学会としても必要かなという気はします.

西尾: 私も今までは, 清野先生がおっしゃったようにど こかの対象物があって, それを可視化にもってきている. そうすると今おっしゃったようなストーリーになるんで す.そうではなくて, 例えばPIV の様に, 可視化情報 のところで何かが生み出されて, それが外に向かって流
れ出すという格好になると，そこでプロパーができるだ ろうと. 個人が意思を持ってそこで活動しないと難しい のかな.

\section{「やっぱり可視化は面白い」}

水上：トラディショナルの可視化が面白いというかやめ られないのは, 自分が予想していたことと全然違ったも のが出てきてしまったというのは非常に面白いですよね. 自分はこうだと思っていたんだけれど, 見てみたら全然 違っていたとか, シミュレーションして合う合わないと いう話が出ましたけれど, シミュレーションの過程が 違っていた, モデルが違っていた, 実際に可視化してみ たらば全然違った現象が起きてしまったとか. それこそ 清野先生ではないけれど, 死んでいるものを見てみたら 全然違った, 生きているのを見たら違ったとか, そうい う何か自分のやっていることが裏切られるのを期待して 可視化やっている部分があるんじゃないかと思うのです. それはすごく研究のモーティベーションになるし, だか らそういう意味では古典的な可視化もやめられないとい うか, 面白いというかね. それで自分はやっていきたい のかなという気はするんです.

西尾: だから見て面白いというのがないと, 我々絶対動 かないですよね.

岡本 : それこそ昔洗濯機の中をずっと親いていた.

水上：それ大事ですよね, 一番. 面白い.

西尾 : それはやはり科学の原点じゃないですか.

清野 : 見ることが面白いというのは.

岡本：そこが最初で最後ですね, 本当に.

清野: 本当にそうですね, それが何なのかという説明を 求め, それがモーティベーションでもあるし.

岡本：今日は, 長い間ありがとうございました，最後に まとめとして, 今後の可視化情報学会の 10 年を考える キーワードを 4 つ挙げて終りにしたいと思います.

\section{On-line Visual Abstract \\ Visual Data Mining \\ 検証の体系化 \\ 可視化情報学プロパーの養成}

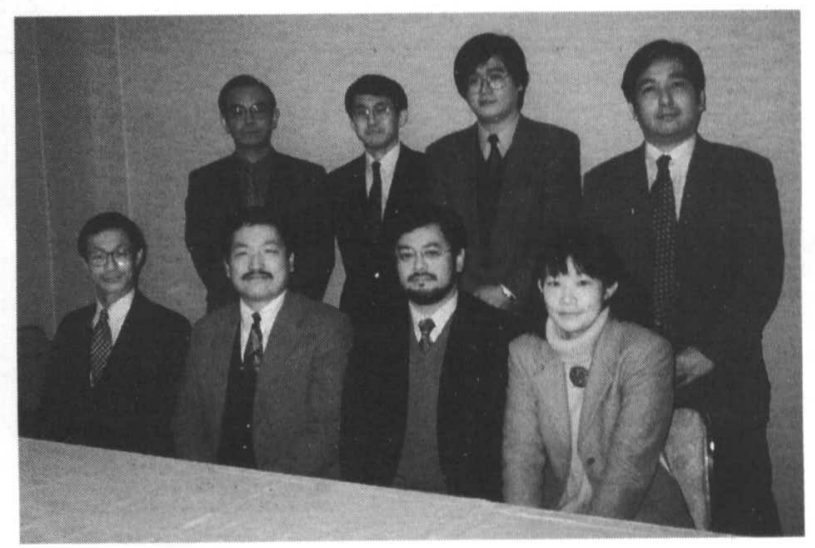

